\title{
Gametogênese e dinâmica da reprodução de Anodontites trapesialis (Lamarck) (Unionoida, Mycetopodidae) no lago Baía do Poço, planície de inundação do rio Cuiabá, Mato Grosso, Brasil
}

\author{
Cláudia T. Callil \& Maria C. D. Mansur \\ Laboratório de Ecologia Animal, Departamento de Biologia e Zoologia, Instituto de Biociências, Universidade Federal de \\ Mato Grosso. Avenida Fernando Corrêa da Costa, 78000-900 Cuiabá, Mato Grosso, Brasil. E-mail: callil@ufmt.br
}

\begin{abstract}
Gametogenesis and dynamics of the reproduction of Anodontites trapesialis (Lamarck) (Unionoida, Mycetopodidae) from Baia do Poço Lake at the Cuiabá River wetland, Mato Grosso, Brazil. The reproductive cycle of Anodontites trapesialis was studied from May 1998 to April 1999. Quantitative analysis of the sexual cycle revealed that the species is exclusively hermaphrodite with separate male and female follicles. Gametogenesis is continuous with peaks of maturation and elimination of gametes during dry season. The period of maximum maturation of the oogenesis was in April and May, when mature oocytes were observed filling the follicles and gonoducts. Spermatogenesis was recognized by a proliferation phase with developing cells with period of maturation since April to July. These cells started to differentiate giving origin to spermatic morulae and free spermatozoa organizing the radial spermatic series. During the period of discharge of the gamets, the majority of follicles presented aggregates of spermatozoa forming the spermballs, which characterize the species as spermatozeugmata. KEY WORDS. Bivalvia; hermaphroditism; Pantanal; sperm morulae; spermatozeugmata.
\end{abstract}

RESUMO. O ciclo reprodutivo de Anodontites trapesialis foi estudado entre os meses de maio de 1998 a abril de 1999. Análises quantitativas dos elementos celulares revelaram que a espécie é exclusivamente hermafrodita com folículos masculinos e femininos separados. A gametogênese é contínua com picos de maturação e eliminação de gametas durante a estação seca. A ovogênese tem seu período de maturação máxima em abril e maio, momento em que óvulos maduros são observados preenchendo os folículos e gonoductos. A espermatogênese foi reconhecida por uma fase proliferativa com células em desenvolvimento e apresentou seu período de maturação entre abril e julho. Estas células se diferenciaram dando origem às mórulas espermáticas e espermatozóides livres, organizando a série espermática radial. Durante o período de liberação dos gametas, a maioria dos folículos apresentou agregados de espematozóides formando esferas espermáticas as "spermballs", as quais caracterizam a espécie como espermatozeugmata.

PALAVRAS-CHAVE. Bivalvia; espermatozeugmatas; mórulas espermáticas; hermafroditismo; Pantanal.

Anodontites trapesialis (Lamarck, 1819) é um bivalve de água doce pertencente à família Mycetopodidae, exclusiva da América do Sul, a qual se diferencia dos demais Unionoida por possuir uma larva do tipo lasídio, parasita temporária de peixes. Nesta família bem como nos Hyriidae, as demibrânquias têm também função de marsúpio, aonde ocorre o desenvolvimento das larvas.

Apesar de vasta a literatura que aborda temas relacionados à reprodução de bivalves de água doce nos diferentes continentes, na América do Sul os trabalhos que descrevem o ciclo sexual de bivalves nativos estão restritos a BonetTo \& Ezcurra (1962a, b), Curial \& Lange (1975), Peredo \& Parada (1986), Maldonado et al. (1990), Avelar \& Mendonça (1998), Beasley et al. (2000), Semenas \& BRugni (2002). A maior parte destas publica- ções refere-se às espécies de representantes de Hyriidae. Apenas Bonetto \& Ezcurra (1962a, b) e Maldonado et al. (1990) retratam alguns aspectos relacionados à reprodução de duas espécies de Mycetopodidae, Anodontites trapesialis forbesianus (Lea, 1860) e A. soleniformis (Orbigny, 1835) respectivamente. Mesmo se tratando de um grupo diferenciado, freqüente, abundante e de ampla distribuição geográfica, ainda não existem informações básicas disponíveis sobre a reprodução e dinâmica populacional das espécies pertencentes ao gênero Anodontites Bruguière, 1792.

A necessidade de compreender aspectos biológicos e ecológicos deste grupo de organismos surgiu quando CaLLIL \& JunK $(1999,2000)$ avaliaram o papel funcional de algumas espécies de bivalves e gastrópodes que ocorrem no Pantanal, frente à incorporação e biomagnificação de mercúrio, metal utilizado 
indiscriminadamente nos garimpos de ouro, e verificaram a ausência de dados relacionados aos organismos em estudo.

Assim, compondo um conjunto de informações que subsidiaram a elaboração de um protocolo de monitoramento utilizando A. trapesialis como organismos sentinelas e indicadores de alterações ambientais, resultantes de uma tese de doutoramento; o objetivo direto deste estudo é compreender a dinâmica reprodutiva e o ciclo de desenvolvimento dos gametas desta espécie na lagoa Baía do Poço, em Santo Antônio do Leverger, Mato Grosso.

\section{MATERIAL E MÉTODOS}

Afluente do rio Paraguai, o rio Cuiabá é um dos principais corpos de drenagem do Pantanal de Mato Grosso. Suas nascentes estão na Serra Azul e a bacia de drenagem ocupa quase 100.000 $\mathrm{km}^{2}$, com vales íngremes no alto do curso, quando recebe pela margem esquerda o rio Manso, alarga-se nas proximidades do município de Cuiabá e forma extensas áreas inundáveis. A Baía do Poço $\left(56^{\circ} 55^{\prime} \mathrm{W}\right.$ e $\left.16^{\circ} 01^{\prime} \mathrm{S}\right)$ é uma lagoa marginal em forma de ferradura, com aproximadamente $1.200 \mathrm{~m}$ de extensão por 120 $\mathrm{m}$ de largura totalizando uma área de $27.877 \mathrm{~m}^{2}$. É considerada como área de inundação adjacente ao rio Cuiabá, estando conectada permanentemente a este, exceto em períodos de drásticas estiagens. Entre abril de 1998 e março de 1999, na época de chuvas (novembro a março), a lâmina de água da Baía do Poço aumentou cerca de 3,0 m, expandindo os limites marginais da lagoa e inundando a vegetação adjacente. As características físico-químicas da água são determinadas principalmente pelo pulso de inundação periódico, definido por um ciclo sazonal de seca e cheia (Junk et al. 1989).

Durante o período de estudos, as principais variáveis físicas e químicas da água foram monitoradas mensalmente, profundidade e transparência foram obtidas com disco de Secchi e a temperatura $\left({ }^{\circ} \mathrm{C}\right)$ com Termistor Oximêtro 200 WSI, ao passo que os valores de $\mathrm{pH}$ foram aferidos com auxilio de $\mathrm{pHmetro}$ 100 YSI, o Oxigênio Dissolvido (mg. $\mathrm{l}^{-1}$ ) com Oximêtro 200WSI e a condutividade elétrica $\left(\mu \mathrm{S} . \mathrm{cm}^{-1)}\right.$ com Condutivímetro OREON 1150A+.

O sedimento foi amostrado com um pegador de fundo, tipo Petersen modificado $\left(0,0416 \mathrm{~m}^{2}\right)$ e a concentração de matéria orgânica foi determinada por calcinação e o padrão granulométrico através de fracionamento em peneiras de 2,0 $\mathrm{mm} ; 1,0 \mathrm{~mm} ; 0,5 \mathrm{~mm}$; 0,25 mm; 0,125 $\mathrm{mm}$ e 0,063 mm.

Entre maio de 1998 e abril de 1999, foram coletados cerca de dez bivalves a cada mês. Para a amostragem dos bivalves, durante o período de cheia foi usada uma draga de arrasto e na seca, a coleta procedeu-se de forma manual tateando o substrato para localizar os indivíduos. Para o transporte destes ainda vivos, recipientes plásticos foram adaptados com um sistema de aeração e contendo água do local de origem. No Laboratório de Ecologia Animal do NEPA/IB/UFMT, os exemplares foram acondicionados em tanques com capacidade de 1000 litros até o momento da manipulação para a obtenção dos dados.
Para o estudo da dinâmica da reprodução, o comprimento total da concha ( $\mathrm{Lt}, \mathrm{mm}$ ) foi medido com um paquímetro digital (curso $150 \mathrm{~mm} / 6$ " resol. 0,01 mm e 0,0005"). Relacionadas ao peso dos indivíduos, foram consideradas três variáveis: o peso total $(\mathrm{Wt}, \mathrm{g})$, correspondendo ao peso completo do indivíduo; o peso do corpo ( $\mathrm{Wb}, \mathrm{g}$ ), o qual corresponde ao peso das partes moles do corpo após remoção das valvas e retirada da água presente no espaço intervalvar e na cavidade palial; e o peso da concha (Ws, g) correspondente ao peso das duas valvas. Estas variáveis foram registradas com o organismo fresco (peso úmido) utilizando uma balança analítica (definição 0,000).

O material testemunho encontra-se depositado na Coleção de Moluscos do Laboratório de Ecologia Animal, Instituto de Biociências, Universidade Federal de Mato Grosso sob os seguintes números: 0074, 0075, 0077, 0078, 0080, 0082, 0085 , 0086, 0088, 0090, 0093, 0094, 0096, 0098 e 0193.

Após a obtenção das variáveis biométricas, foi retirado aproximadamente $1 \mathrm{~cm}^{3}$ de tecido da porção mediana central da massa visceral. Este material foi fixado em solução de Bouin por 24 horas, lavado sucessivas vezes e mantido em álcool a 70\%. Foi utilizado o protocolo histológico padrão, iniciando com uma série crescente de desidratação em álcool, seguida de diafanização em xilol e inclusão em parafina histológica. Os cortes foram feitos em micrótomo manual com espessura de $6 \mu \mathrm{m}$ e a coloração seguiu o método bicrômico usual de Hematoxilina-Eosina.

Entre os 100 indivíduos amostrados, 73 bivalves tiveram a massa visceral analisada histologicamente. Nestas utilizamos microscópio óptico e para facilitar a interpretação das lâminas e descrição dos estágios de desenvolvimento gonadal, foram obtidas imagens de todos os exemplares microtomizados, em aumento de 50, 100, 400 e 1000x, através de um sistema de edição, acoplado a um microscópio Zeiss-Axiolab. Foi necessária a categorização de uma série de critérios qualitativos relacionados às características histológicas no sentido de reconhecer diferentes estágios sucessivos de desenvolvimento: a) folículos: abundância, forma, tenacidade, altura das células epiteliais, presença de células primordiais agregadas; b) ductos foliculares: estrutura epitelial, ciliação e presença de substância amarela intra e extracelular; c) células primordiais: presença, tamanho relativo, densidade (coloração), localização dentro do folículo, formação de séries periféricas, diferenciação; d) gametas femininos: tamanho, forma, tenacidade, coloração, presença de vitelo, localização e preenchimento do folículo e; f) gametas masculinos: presença, quantidade e desenvolvimento da série espermática radial, presença e quantidade de mórulas espermáticas, presença e agregação de espermatozóides, formação de esferas de espermas.

No sentido de evitar a subjetividade oriunda da caracterização qualitativa, normalmente utilizada para reconhecer o ciclo sexual em moluscos bivalves e muitos outros organismos aquáticos, optou-se também por aplicar métodos quantitativos. A partir da análise e quantificação dos elementos celulares (Jones et al. 1986, HagGerTy et al. 1995) foi possível completar 
as informações relativas à gametogênese, bem como confirmar o período de eliminação dos gametas de A. trapesialis.

A ovogênese foi quantificada através do valor médio de cada tipo celular em dez folículos de cada espécime. Foram considerados dois tipos celulares. Ovócitos em desenvolvimento (OC): células pequenas, aproximadamente $12,5 \mu \mathrm{m}$, e periféricas, densamente coradas por Eosina, agregadas ou não ao epitélio folicular. Óvulos em vitelogênese e maduros (OV): células maiores, aproximadamente $50,0 \mu \mathrm{m}$, ovaladas ou hexagonais quase sempre localizadas no centro do folículo e preenchidas por grânulos translúcidos de vitelo. Também foram obtidas as medidas do diâmetro dos óvulos em desenvolvimento (tOV) que corresponde ao diâmetro de um óvulo vitelínico em cada folículo. Procurou-se obter as medidas dos óvulos nos quais o plano de corte atravessava o núcleo.

Para quantificar a espermatogênese, foram considerados quatro tipos celulares. Células em desenvolvimento (CD) nesta categoria são consideradas partes das células que compõe a série espermática: espermatogônias, espermatócitos de primeira ordem, espermatócitos de segunda ordem e espermátides. Mórulas espermáticas (ME): o termo mórula, embora inadequado, é o que tem sido empregado para designar as formas de agregação celular, de configuração semelhante ao estágio embrionário de mórula, independente do posicionamento na série espermática. Espermatozóides (ESP): gametas maduros, já diferenciados e independentes. Esferas de espermas (EE) denominadas de "spermballs", como o próprio nome diz, são agregados esféricos de espermatozóides maduros, os quais estão unidos pelo acrossoma, os flagelos são livres e possuem movimento. Os tipos celulares descritos foram contados ao longo de um transecto de 0,1 mm no sentido epitélio-lúmen, sob aumento de 1000x, em dez folículos por espécime analisado.

Utilizamos análises de variância simples e multivariada para constatar se as diferenças entre os elementos celulares foram significativas. O teste de Scheffé foi considerado na análise a posteriori, no sentido de verificar diferenças isoladas entre variáveis.

\section{RESULTADOS}

\section{Caracterização limnológica}

A água na lagoa Baía do Poço, durante este estudo, manteve-se neutra com tendências à alcalina nos períodos de vazante. $\mathrm{O}$ pH variou entre 6,0 e 8,5 e a condutividade elétrica variou entre 33,0 e 72,3 $\mu \mathrm{S} / \mathrm{L}$, característicos dos corpos d'água da região. Os valores registrados para a temperatura da água oscilaram entre 29,3 e $34,7^{\circ} \mathrm{C}$ e a transparência variou entre 12,5 e $45 \mathrm{~cm}$ sendo que a turbidez esteve entre 84 e $299 \mathrm{ntu}$. O substrato apresentou-se preferencialmente arenoso, rico em matéria orgânica, com áreas de silte próximas aos locais utilizados pela população. Análises relacionadas à concentração de matéria orgânica no sedimento revelaram que as concentrações mais elevadas ocorrem durante a cheia e vazante entre os meses de dezembro a maio (Fig. 1).

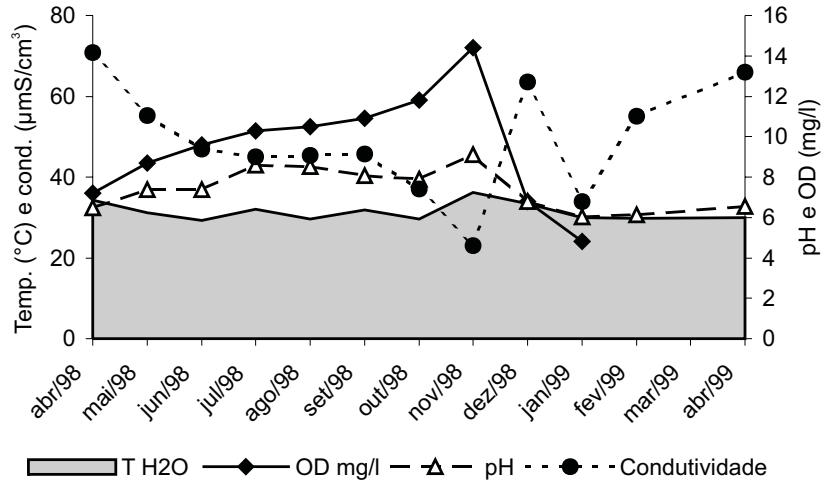

Figura 1. Variação sazonal dos parâmetros ambientais do Lago Baía do Poço, medidos durante o período de estudos. $\left(\mathrm{TH}_{2} \mathrm{O}\right)$ Temperatura da água $\left({ }^{\circ} \mathrm{C}\right),(\mathrm{OD})$ concentração de oxigênio dissolvido ( $\mathrm{mg} / \mathrm{l})$, (cond) condutividade elétrica da água $\left(\mu \mathrm{S} / \mathrm{cm}^{3}\right)$ e $\mathrm{pH}$.

\section{Aspectos populacionais}

A tabela I apresenta a variação mensal dos parâmetros biométricos considerados neste estudo ao longo do período amostrado. Com base na análise histológica, os indivíduos com comprimento total médio de $43,73 \pm 9,87 \mathrm{~mm}$ e peso total médio em torno de 30,60 \pm 7,25 g (Figs 2 e 3) podem ser considerados jovens ou com gônadas imaturas. Os valores referentes ao comprimento total (Lt) dos indivíduos adultos (que apresentam folículos contendo gametas), variaram entre 47,37 e 134,26 mm, com valor médio de 92,54 $\pm 22,78 \mathrm{~mm}$ (Fig. 2). A amplitude dos valores referentes ao peso total $(\mathrm{Wt})$ foram maiores, variando entre 8,97 e 220,42 g com média de $97,18 \pm 58,85$ g (Fig. 3). O peso das partes moles do corpo ( $\mathrm{Wb}$ ), variou entre 2,29 e 79,28 g com média de 33,40 $\pm 21,10$ g. A relação entre o peso do corpo e o peso total, índice de condição (Ic), demonstrou que este representa cerca $37,5 \%$ do peso total, apresentando pequenas variações com limites entre 22,3 e 45,5\% (Fig. 3).

Categoria sexual e caracterização das estruturas gametogênicas

Dentre os 73 indivíduos que tiveram a massa visceral analisada histologicamente, 63 apresentaram folículos femininos e masculinos (86,30\% hermafroditas), fato que caracteriza esta espécie na Baía do Poço, como hermafrodita funcional e simultâneo. Entre os demais, 2 indivíduos (2,73\%) possuíam folículos exclusivamente masculinos e $8(10,95 \%)$ não demonstraram atividade reprodutiva, nem mesmo sinais de formações foliculares.

Em A. trapesialis, bem como na maioria dos bivalves Unionoida, os folículos gametogênicos estão presentes na porção da massa visceral situada na região central e postero-dorsal do pé. Os gametas são formados no interior de folículos dispersos nesta parte da massa visceral. Estes apresentam uma estrutura ramificada arborescente, semelhantes à ácinos glandulares, caracterizados por pequenas dilatações em forma de pequenos sacos. Entremeando a estrutura folicular observamos feixes transversos de fibras musculares que sustentam todo o conjunto (Figs 4-11).

Revista Brasileira de Zoologia 24 (3): 825-840, setembro 2007 

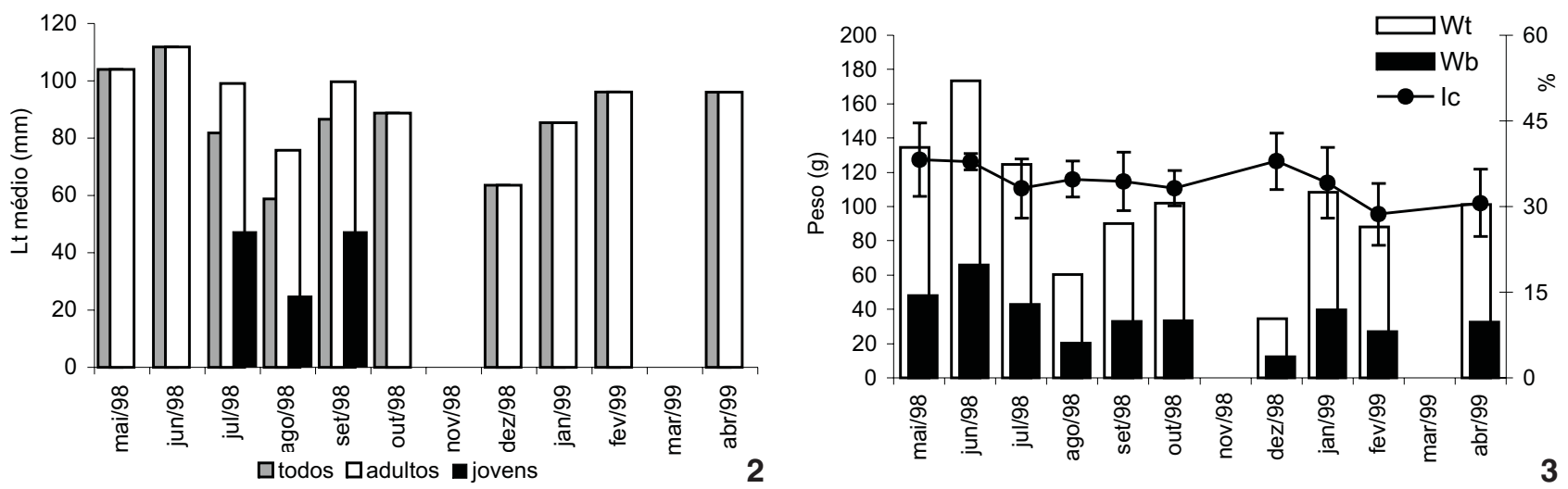

Figuras 2-3. Distribuição mensal dos valores médios do comprimento total (Lt, $\mathrm{mm}$ ) (2) e dos valores médios dos parâmetros relacionados ao peso (3) de Anodontites trapesialis amostrados na Baía do Poço, Santo Antônio de Leverger, Mato Grosso. (Wt) Peso total (g), $(\mathrm{Wb})$ peso das partes moles do corpo $(\mathrm{g})$.

Tabela I. Variação mensal aos parâmetros biométricos de Anodontites trapesialis utilizados nos estudo da gametogênese. (Lt) Comprimento total da concha $(\mathrm{mm}),(\mathrm{Wt})$ peso total do indivíduo $(\mathrm{g}),(\mathrm{Wb})$ peso das partes moles do corpo (g), (Ws) peso da concha (g), (Ic) índice de condição (\%).

\begin{tabular}{lrrrrrr}
\hline \multicolumn{1}{c}{ Meses } & $\mathrm{n}$ & \multicolumn{1}{c}{$\mathrm{Lt}(\mathrm{mm})$} & \multicolumn{1}{c}{ Wt $(\mathrm{g})$} & $\mathrm{Wb}(\mathrm{g})$ & \multicolumn{1}{c}{ Ws $(\mathrm{g})$} & $\mathrm{Ic} \%$ \\
\hline Junho/1998 & 4 & $111,83 \pm 5,21$ & $173,43 \pm 28,65$ & $65,68 \pm 11,24$ & $46,86 \pm 8,95$ & $37,86 \pm 1,43$ \\
Julho & 9 & $100,99 \pm 25,82$ & $124,78 \pm 66,27$ & $42,76 \pm 23,73$ & $33,6 \pm 18,62$ & $33,18 \pm 5,20$ \\
Agosto & 7 & $78,41 \pm 30,43$ & $60,26 \pm 56,07$ & $20,27 \pm 18,14$ & $18 ., 2 \pm 17,37$ & $34,79 \pm 3,15$ \\
Setembro & 8 & $93,18 \pm 29,59$ & $89,92 \pm 58,30$ & $32,84 \pm 23,15$ & $28,18 \pm 20,31$ & $34,37 \pm 5,14$ \\
Outubro & 15 & $93,23 \pm 22,60$ & $101,79 \pm 58,06$ & $33,21 \pm 18,34$ & $31,07 \pm 20,44$ & $33,18 \pm 3,08$ \\
Dezembro & 8 & $68,24 \pm 9,38$ & $34,48 \pm 20,86$ & $12,35 \pm 5,05$ & $8,65 \pm 6,44$ & $37,96 \pm 4,93$ \\
Janeiro $/ 1999$ & 3 & $98,88 \pm 22,54$ & $108,27 \pm 63,76$ & $39,60 \pm 28,22$ & $26,21 \pm 16,34$ & $34,19 \pm 6,20$ \\
Fevereiro & 5 & $91,96 \pm 18,09$ & $88,20 \pm 52,13$ & $26,92 \pm 19,48$ & $28,87 \pm 20,28$ & $28,64 \pm 5,44$ \\
Abril & 9 & $98,20 \pm 16,57$ & $101,30 \pm 39,42$ & $32,53 \pm 15,62$ & $32,82 \pm 13,33$ & $30,62 \pm 5,90$ \\
\hline
\end{tabular}

Os folículos são exclusivamente femininos ou masculinos. Entre todos os indivíduos analisados, foi observado apenas um folículo misto em um único indivíduo (Fig. 18). Os gametas são produzidos a partir de células primordiais do epitélio folicular que sofrem diferenciação ao longo do processo de maturação. Na maioria dos casos, óvulos e espermatozóides foram eliminados através de ductos exclusivos, mas eventualmente também foram encontrados ao longo dos ductos, óvulos maduros circundados por gametas masculinos (Fig. 10) fato que oferece condições para a ocorrência de autofecundação.

\section{Desenvolvimento dos folículos gametogênicos}

A partir de uma avaliação histológica ao longo do período amostrado, foram caracterizados cinco estágios de desenvolvimento folicular.

I) Inatividade sexual (Fig. 4): ausência de indícios foliculares. Geralmente identificado em indivíduos jovens, antes de iniciar atividade reprodutiva. Pode ocorrer também em indivíduos, os quais passaram pelo período de eliminação dos game- tas. Nestas circunstâncias, há resquícios foliculares esparsos pela massa visceral, podendo apresentar elementos celulares remanescentes em reabsorção.

II) Proliferação celular - início de maturação (Fig. 5): os exemplares neste estágio caracterizam-se por apresentarem folículos distribuídos pela massa visceral. Os folículos estão preenchidos por células basófilas (folículos masculinos) ou acidófilas (folículos femininos), densas, pequenas e de tamanho uniforme. Estas células, denominadas de elementos proliferativos (ovogônias ou espermatogônias), podem apresentar-se organizadas em camadas periféricas liberando o lúmem central (folículos femininos) (Figs 17 e 20) ou preenchendo por completo o espaço intrafolicular (folículos masculino) (Figs 31 e 32). Nos folículos masculinos, não há indícios de diferenciação celular e formação de séries espermáticas. A presença de uma grande quantidade de mórulas espermáticas é característica neste estágio (Fig. 32).

III) Diferenciação celular - maturação (Figs 6 e 7): nesta fase os folículos ocupam de forma generalizada a massa visceral. O epitélio folicular simples é bem definido, composto por cé- 

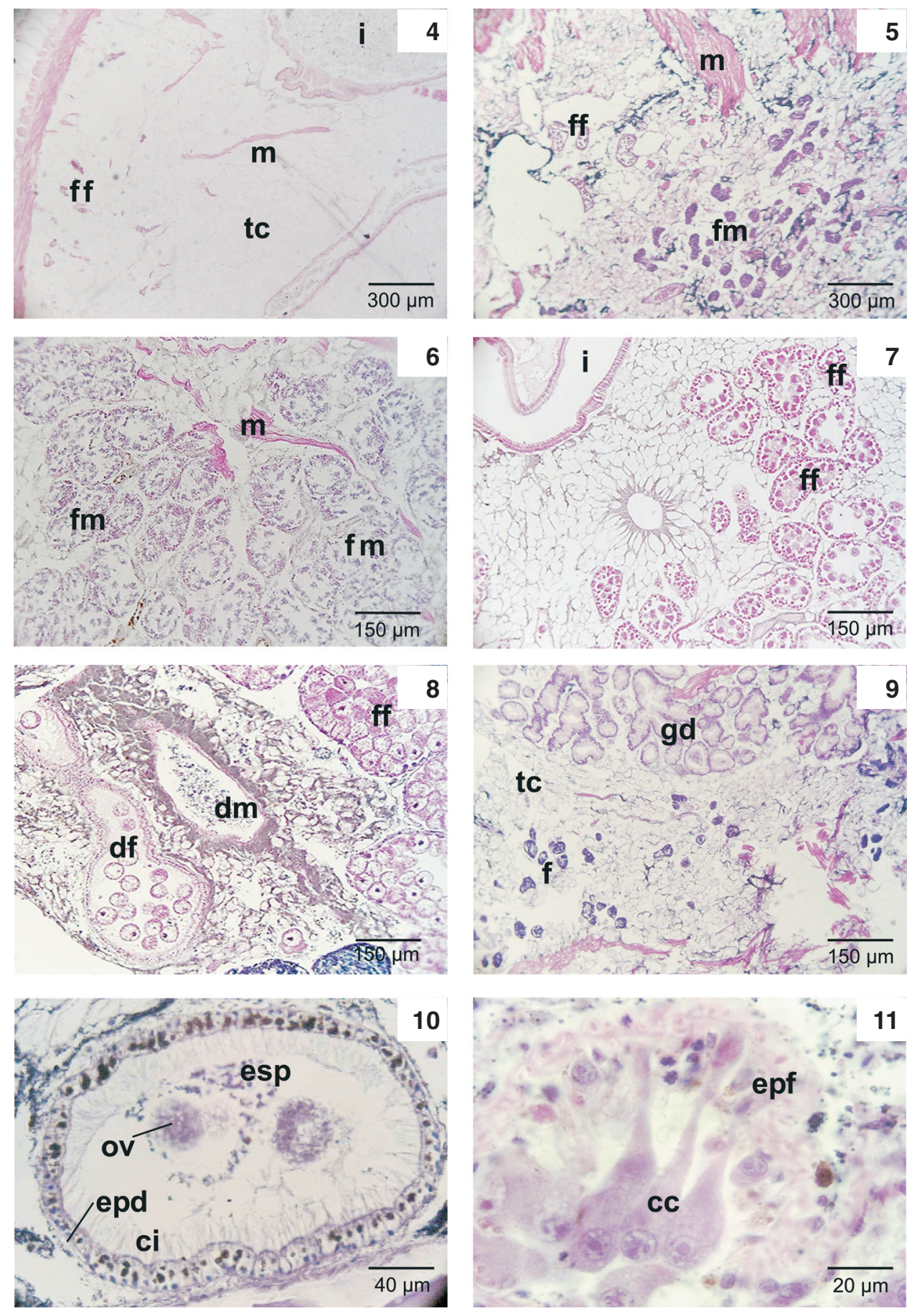

Figuras 4-11. Estádios de desenvolvimento folicular: (4) I repouso; (5) II proliferação celular; (6) III diferenciação celular-maturação (folículo masculino); (7) III diferenciação celular-maturação (folículo feminino); (8) IV eliminação-maturo; (9) V esgotamento; (10) gonoducto com gametas femininos e masculinos; (11) células caliciformes. (cc) Células caliciformes, (ci) cílios, (df) ducto feminino, (dm) ducto masculino, (epd) epitélio do ducto, (epf) epitélio do folículo, (esp) espermatozóide, (ff) folículo feminino, (fm) folículo masculino, (gd) glândula digestiva, (i) intestino, (m) músculo, (ov) óvulo, (tc) tecido conjuntivo. 
lulas pavimentosas com núcleos evidentes. Nos folículos masculinos, células gametogênicas apresentam-se organizadas em pacotes periféricos. É possível observar espermatogônias e espermatócitos configurando inicialmente a série espermática radial. No lúmen podem ocorrer nuvens de espermatozóides (Figs 24 e 25). Em folículos femininos, observa-se o aumento no tamanho dos ovócitos devido ao acúmulo de substância nutritiva. Neste momento ocorre a migração de ovócitos em desenvolvimento para o centro folicular, podendo assumir uma forma hexagonal conforme acumulam e avançam no processo de vitelogênese (Fig. 22).

IV) Eliminação - maturo (Figs 8 e 10): período caracterizado principalmente pela presença de grande quantidade de espermatozóides, tanto no lúmem folicular, quanto ao longo dos ductos (Figs 34 e 35). É intensa a produção de grânulos compostos por uma substância amarela translúcida no epitélio dos gonoductos, a qual se acentua durante a fase de eliminação dos gametas. Normalmente acumulados no interior das células epiteliais dos ductos masculinos, estes grânulos também podem ser encontrados dispersos pela massa visceral, principalmente ao redor dos folículos masculinos (Figs 14, 25 e 35). Ainda durante o processo de eliminação dos gametas, pode ocorrer a proliferação de novos elementos. Nos folículos femininos, este evento é caracterizado pela presença de óvulos maduros no lúmem folicular, simultaneamente com a produção de várias séries periféricas de ovogônias. A maioria destas novas células está conectada ao epitélio folicular através de um pedúnculo, o qual aparentemente está relacionado ao preenchimento das células em processo de vitelogênese, a partir das células nutritivas do epitélio folicular (Figs 16, 20 e 21). Nos folículos masculinos, é comum a ocorrência de uma ou várias esferas de espermas, "spermballs" (Fig. 27), as quais também podem ser visualizadas ao longo dos ductos (Fig. 25).

V) Esgotamento: aqui ocorre a eliminação total dos game- tas. O epitélio folicular é disforme conferindo um contorno irregular para os folículos. Nos folículos femininos raramente ocorrem óvulos remanescentes da fase de eliminação, geralmente em processo de lise e ou reabsorção celular. Os folículos masculinos, quando esvaziados, são caracterizados pela reversão, apresentando apenas fragmentos dispersos de folículos (Fig. 9), momento em que se observou apenas vestígios de pequenos sacos contendo raros gametas em reabsorção, caracterizando assim uma fase de esgotamento e inatividade gonadal. Neste momento, período de eliminação dos gametas, foram observadas larvas nas demibrânquias internas (Figs 36-39).

A tabela II e a figura 40 foram elaboradas a com base em análises qualitativas relacionadas à presença e ausência dos elementos foliculares. Nestas foi possível demonstrar os principais eventos que ocorreram nos folículos gametogênicos ao longo do período amostrado. A variação mensal do número de indivíduos encontrados nos diferentes estágios de desenvolvimento gonadal está representada para ambos os tipos foliculares na figura 41, onde ficam evidentes os períodos de proliferação e diferenciação celular (II - janeiro/fevereiro), maturação (III - abril a setembro), eliminação dos gametas e incubação das larvas (IV - abril a junho) e esgotamento e reversão folicular ( $\mathrm{V}$ - agosto a dezembro).

\section{Ciclo sexual feminino}

A descrição dos eventos mensais relacionados à produção de gametas femininos ao longo do período amostrado encontra-se detalhada na tabela III. A oscilação dos valores referentes ao tamanho do folículo, número de ovócitos, número de óvulos e tamanho dos óvulos (Fig. 42) apresentaram diferenças significativas quando consideradas ao longo do período amostral (MANOVA, Wilks lambda $=0,205$ df $1=36$, df $2=1605$, $\mathrm{p}<0,0001)$. A variação mensal dos valores médios e respectivos desvios das variáveis consideradas encontram-se especificados na tabela IV.

Tabela II. Síntese dos eventos mensais da gametogênese em Anodontites trapesialis amostrados na Baía do Poço, Santo Antônio do Leverger, Mato Grosso. (CP) Células primordiais, (Ei) espermatozóides isolados, (EO) eliminação de óvulos, (ES) esferas de espermatozóides, (FV) folículo esvaziado, (ME) mórulas espermáticas, (OD) ovócitos em desenvolvimento, (OM) óvulos maduros, (SER) série espermática radial.

\begin{tabular}{|c|c|c|c|c|c|c|c|c|c|c|}
\hline \multirow{2}{*}{ Meses } & \multicolumn{5}{|c|}{ Folículos femininos } & \multicolumn{5}{|c|}{ Folículos masculinos } \\
\hline & $\mathrm{CP}$ & OD & OM & EO & $\mathrm{FV}$ & $\mathrm{CP}$ & ME & SER & $\mathrm{Ei}$ & ES \\
\hline Maio/1998 & & $x$ & $\mathrm{x}$ & $x$ & & $x$ & $x$ & $x$ & $x$ & \\
\hline Junho & & $x$ & $x$ & $x$ & & $x$ & $x$ & $x$ & $x$ & \\
\hline Julho & $x$ & $x$ & $x$ & $x$ & $x$ & $x$ & $x$ & $x$ & $x$ & $x$ \\
\hline Agosto & $x$ & & & & $x$ & & $x$ & $x$ & $x$ & $x$ \\
\hline Setembro & & $x$ & & & & $x$ & $x$ & & $x$ & \\
\hline Outubro & & $x$ & $x$ & $x$ & $x$ & & $x$ & $x$ & $x$ & \\
\hline Dezembro & $x$ & & & & $x$ & $x$ & & & & \\
\hline Janeiro/1999 & $x$ & $x$ & & & & $x$ & $x$ & & $x$ & \\
\hline Fevereiro & $x$ & $x$ & & & & $x$ & $x$ & & & \\
\hline Abril & & & $x$ & $x$ & & & & $x$ & $x$ & \\
\hline
\end{tabular}

Revista Brasileira de Zoologia 24 (3): 825-840, setembro 2007 
Tabela III. Caracterização mensal da gametogênese nos folículos femininos de Anodontites trapesialis na Baía do Poço, Santo Antônio do Leverger, Mato Grosso.

\begin{tabular}{|c|c|}
\hline Meses & Folículos femininos \\
\hline Maio e junho & $\begin{array}{l}\text { Folículos grandes limitados por epitélio folicular disforme. Presença de óvulos maduros, grandes e repletos de } \\
\text { vitelo, porém de contorno irregular. Células pequenas e periféricas ocorrem sempre associadas ao epitélio folicular } \\
\text { (Figs } 12 \text { e 13). Ao longo dos ductos, onde gametas femininos sempre estão presentes, ocorrem grânulos de } \\
\text { substância amarela intra e extracelular (Fig. 14). Há também pequenos grânulos desta substância, distribuídos por } \\
\text { entre os folículos. }\end{array}$ \\
\hline Julho a setembro & $\begin{array}{l}\text { Proliferação celular parcial caracterizada pela reversão folicular (Fig. 15): folículos pequenos, disformes e esparsos } \\
\text { pela massa visceral. Presença abundante de tecido interfolicular. Epitélio folicular espesso, muitas vezes com células } \\
\text { pequenas e disformes aderidas. É comum e freqüente a presença de elementos celulares aderidos ao epitélio } \\
\text { através do pedúnculo de nutrição (Fig. 16). Alguns indivíduos apresentam elementos maduros no lúmem ou } \\
\text { arranjados perifericamente em uma série simples de óvulos (Fig. 17). }\end{array}$ \\
\hline Outubro & $\begin{array}{l}\text { As características foliculares para os indivíduos deste mês são muito semelhantes a aqueles amostrados durante o } \\
\text { período anterior. Entretanto, em outubro houve a eliminação total dos elementos maduros residuais. Foram } \\
\text { encontrados óvulos maduros em folículos masculinos (Fig. 18). }\end{array}$ \\
\hline Dezembro & $\begin{array}{l}\text { Total reversão folicular e sinais de início de gametogênese. Presença rara e esporádica de sinais foliculares dispersos } \\
\text { pela massa visceral (Fig. 19). Nestes, o epitélio inicia o processo de proliferação, caracterizado pelo espessamento } \\
\text { e formação de células primordiais, que quando presentes sempre estão localizadas na periferia do folículo. }\end{array}$ \\
\hline Janeiro e fevereiro & $\begin{array}{l}\text { Proliferação celular intensa. Formação ativa de gametas. De forma ovalada e uniforme os folículos recuperam } \\
\text { espaço na massa visceral. O epitélio folicular apresenta-se espesso (Fig. 20). A maioria dos elementos celulares } \\
\text { recém formados (ovogônias) ainda está ligada ao epitélio pelo pedúnculo de nutrição. O lúmem folicular não } \\
\text { apresenta elementos maduros (Fig. 21). }\end{array}$ \\
\hline Abril & $\begin{array}{l}\text { Maturação máxima. Folículos femininos estão repletos de elementos maduros (Fig. 22). Arredondados e de } \\
\text { tamanho uniforme, os óvulos estão grandes }(60 \mu \mathrm{m}) \text { e translúcidos, preenchidos de vitelo (Fig. 23). } \\
\text { Freqüentemente é possível visualizar o núcleo do gameta, de aparência densa e central. A presença de óvulos nos } \\
\text { ductos é constante (Fig. 23). }\end{array}$ \\
\hline
\end{tabular}

Tabela IV. Variação mensal dos parâmetros considerados para os folículos femininos em Anodontites trapesialis amostrados na Baía do Poço, Santo Antônio do Leverger, Mato Grosso. (Tam F) Comprimento máximo do folículo $(\mu \mathrm{m}),(\mathrm{OC})$ número de ovócitos, (OV) número de óvulos, (TOV) diâmetro do óvulo $(\mu \mathrm{m})$.

\begin{tabular}{lcrrrr}
\hline \multicolumn{1}{c}{ Meses } & Tam F & OC & OV & TOV \\
\hline Mai/1998 & $5,70 \pm 2,45$ & $4,70 \pm 3,96$ & $19,09 \pm 8,30$ & $1,92 \pm 0,41$ \\
Junho & $3,16 \pm 0,98$ & $9,93 \pm 8,20$ & $13,35 \pm 10,78$ & $1,60 \pm 0,53$ \\
Julho & $3,07 \pm 1,56$ & $7,07 \pm 7,06$ & $16,59 \pm 7,01$ & $1,60 \pm 0,39$ \\
Agosto & $2,21 \pm 1,67$ & $5,93 \pm 4,65$ & $6,65 \pm 7,82$ & $0.78 \pm 15,86$ \\
Setembro & $2,72 \pm 1,20$ & $7,34 \pm 6,29$ & $14,68 \pm 10,65$ & $1,52 \pm 0,94$ \\
Outubro & $2,44 \pm 1,30$ & $12,08 \pm 6,92$ & $8,49 \pm 10,39$ & $1,03 \pm 0,83$ \\
Dezembro & $1,37 \pm 0,88$ & $19,12 \pm 9,93$ & $2,42 \pm 1,86$ & $0,40 \pm 0,30$ \\
Janeiro/1999 & $2,81 \pm 1,34$ & $20,00 \pm 8,49$ & $13,80 \pm 10,95$ & $1,26 \pm 0,57$ \\
Fevereiro & $1,27 \pm 0,43$ & $38,83 \pm 18,64$ & $10,57 \pm 7,60$ & $1,32 \pm 0,65$ & $1,95 \pm 0,21$ \\
Abril & $5,49 \pm 2,08$ & $4,85 \pm 3,63$ & $24,80 \pm 5,86$ & \\
\hline
\end{tabular}

O tamanho do folículo variou pouco durante os meses amostrados. Entretanto esteve maior durante os meses de abril e maio, diferindo significativamente dos valores referentes aos demais meses ( $\mathrm{F}=38,22$, d.f. $=9, \mathrm{p}<0,001)$. A produção e o desenvolvimento dos gametas femininos têm início com a fase proliferativa que é caracterizada pela presença de ovócitos pequenos e periféricos, quase sempre conectados ao epitélio folicular por meio de um pedúnculo nutritivo (Fig. 20). O número de ovócitos começa a aumentar em outubro, atingindo o pico máximo em fevereiro, com número médio de 33,40 \19,53 ovócitos por folículo, demonstrando uma diferença significativa quando observado o conjunto de dados ao longo do período amostrado $(\mathrm{F}=60,15$, d.f. $=9, \mathrm{p}<0,000)$.

O processo de maturação dos óvulos ocorreu durante o período entre janeiro e abril, quando a Baía do Poço atingiu o nível de água mais elevado. A maturação pôde ser identificada pelo aumento no diâmetro das células, uma vez que os ovócitos possuem em média diâmetro de $15 \mu \mathrm{m}$, e os óvulos maduros 


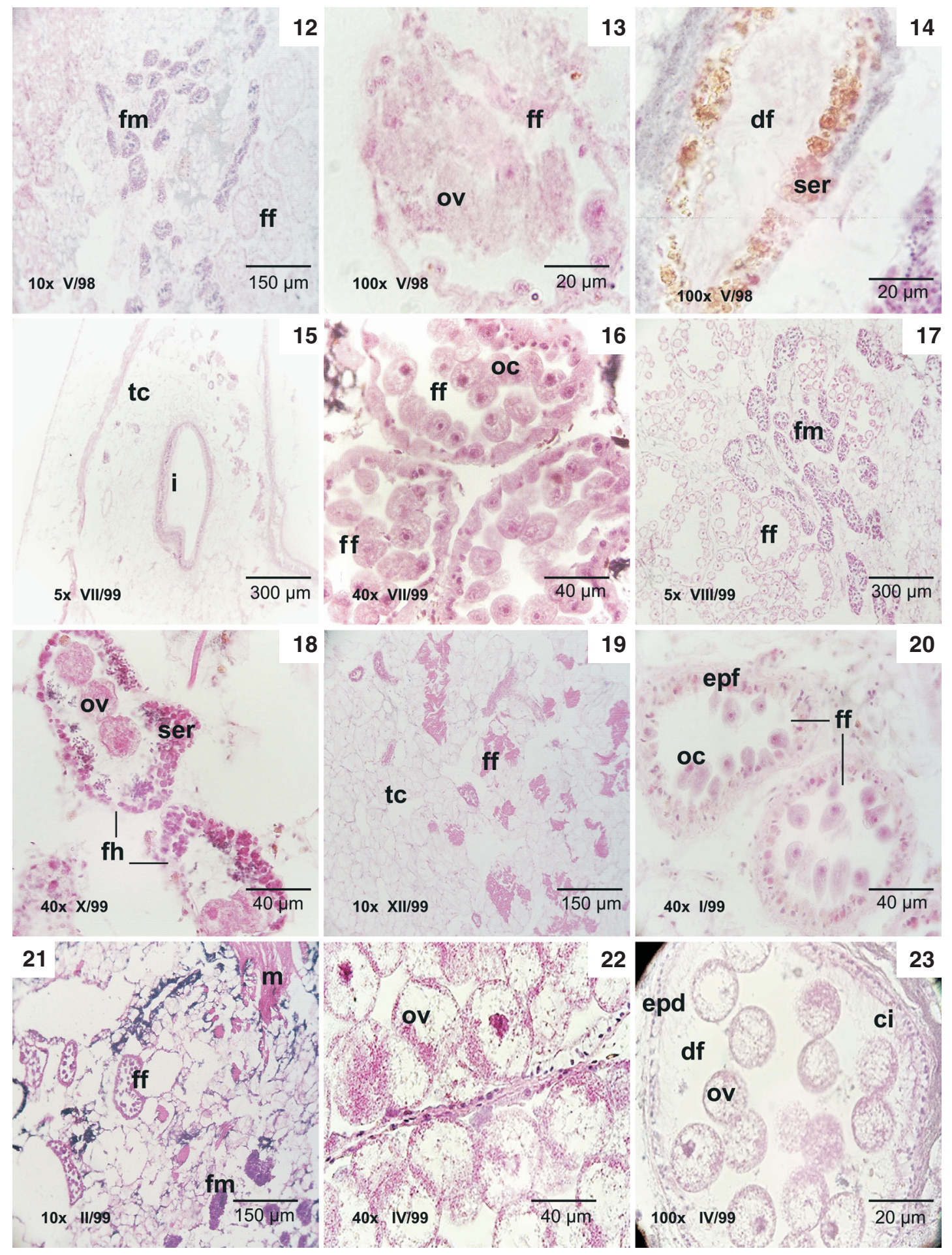

Figuras 12-23. Sucessão mensal dos eventos que ocorrem nos folículos femininos de Anodontites trapesialis amostrados na Baia do Poço, Santo Antônio do Leverger, Mato Grosso. (ci) Cílios, (df) ducto feminino, (epd) epitélio do ducto, (epf) epitélio do folículo, (ff) folículo feminino, (fh) folículo hermafrodita, (fm) folículo masculino, (i) intestino, (m) músculo, (oc) ovócito, (ov) óvulo, (ser) série espermática radial, (tc) tecido conjuntivo. 


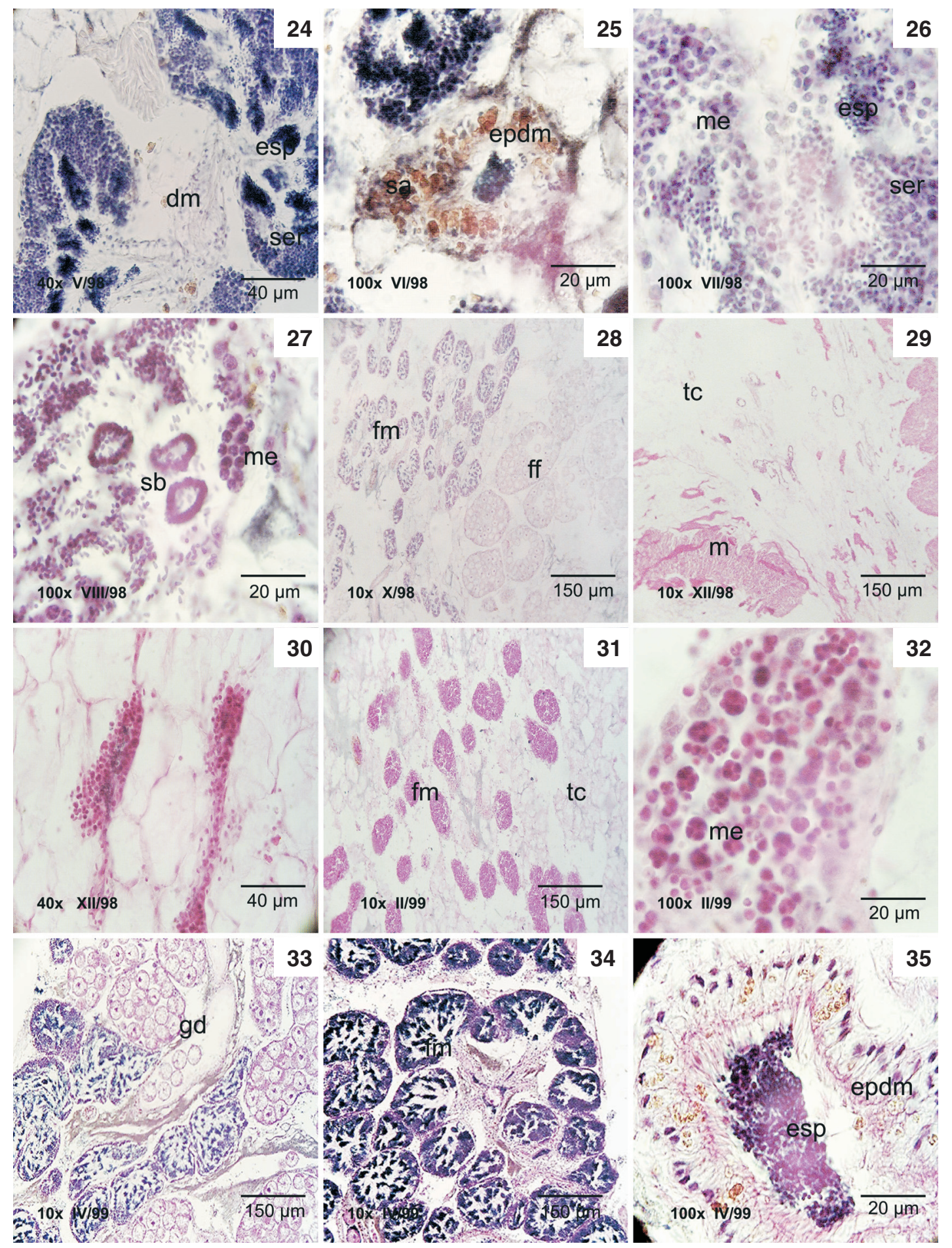

Figuras 24-35. Sucessão mensal dos eventos que ocorrem nos folículos masculinos de Anodontites trapesialis amostrados na Baia do Poço, Santo Antônio do Leverger, Mato Grosso. (dm) Ducto masculino, (esp) espermatozóides, (epdm) epitélio do ducto masculino, (ff) folículo feminino, (fm) folículo masculino, $(\mathrm{gd})$ gonoducto, $(\mathrm{m})$ músculo, (me) mórula espermática, (sb) spermballs, (ser) série espermática radial, (tc) tecido conjuntivo. 


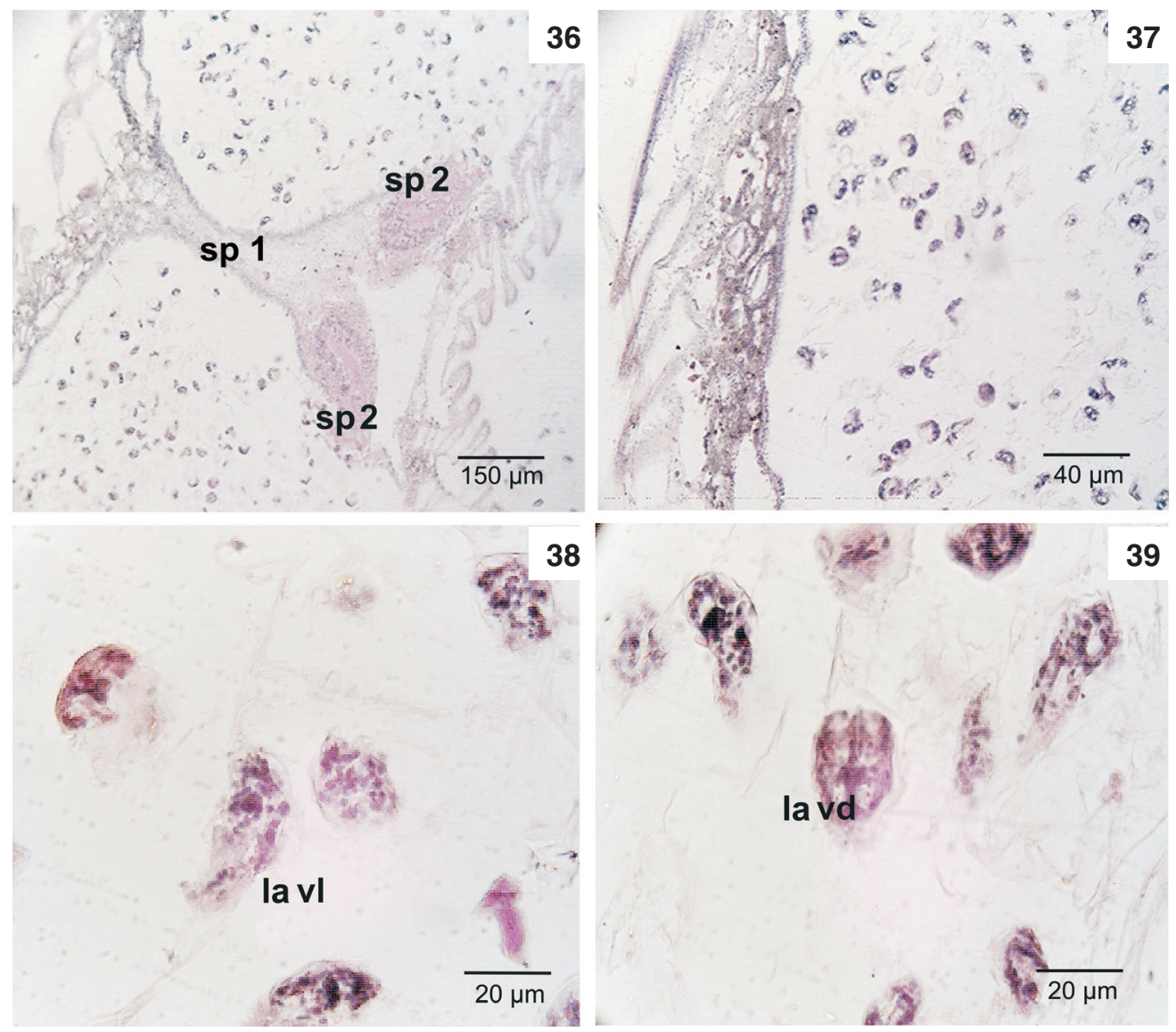

Figuras 36-39. Presença de larvas do tipo lasídio de Anodontites trapesialis observadas no interior do marsúpio, nas demibrânquias internas, simultaneamente ao período de eliminação de gametas, durante o mês de maio/1998. (la vd) Lasídio vista dorsal, (la vl) lasídio vista lateral, (sp1) septo branquial primário, (sp2) septo branquial secundário.
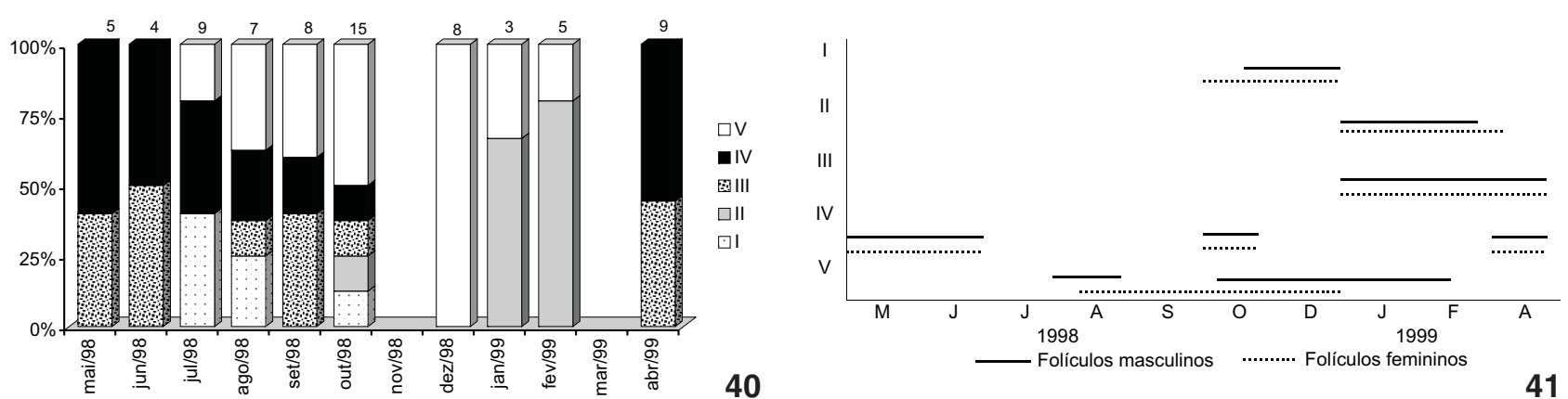

Figuras 40-41. (40) Relação percentual dos indivíduos de Anodontites trapesialis caracterizados nos diferentes estágios de desenvolvimento folicular, amostrados na Baía do Poço, Santo Antônio do Leverger, Mato Grosso; (41) Síntese dos eventos gametogênicos, entre maio de 1998 e abril de 1999. (I) Repouso - inatividade sexual, (II) proliferação celular - inicio de maturação, (III) diferenciação celular - maturação, (IV) maturação máxima e eliminação, (V) esgotamento.

podem atingir até $62,5 \mu \mathrm{m}$ de diâmetro com valor médio em torno de $45 \mu \mathrm{m}$. Na figura 42 é possível observar o sincronismo de eventos entre o aumento do diâmetro celular e número de óvulos maduros demonstrando que estas variáveis estão diretamente relacionadas entre si. Com base no incremento do número de células maduras por folículo (Fig. 16), no aumento no 

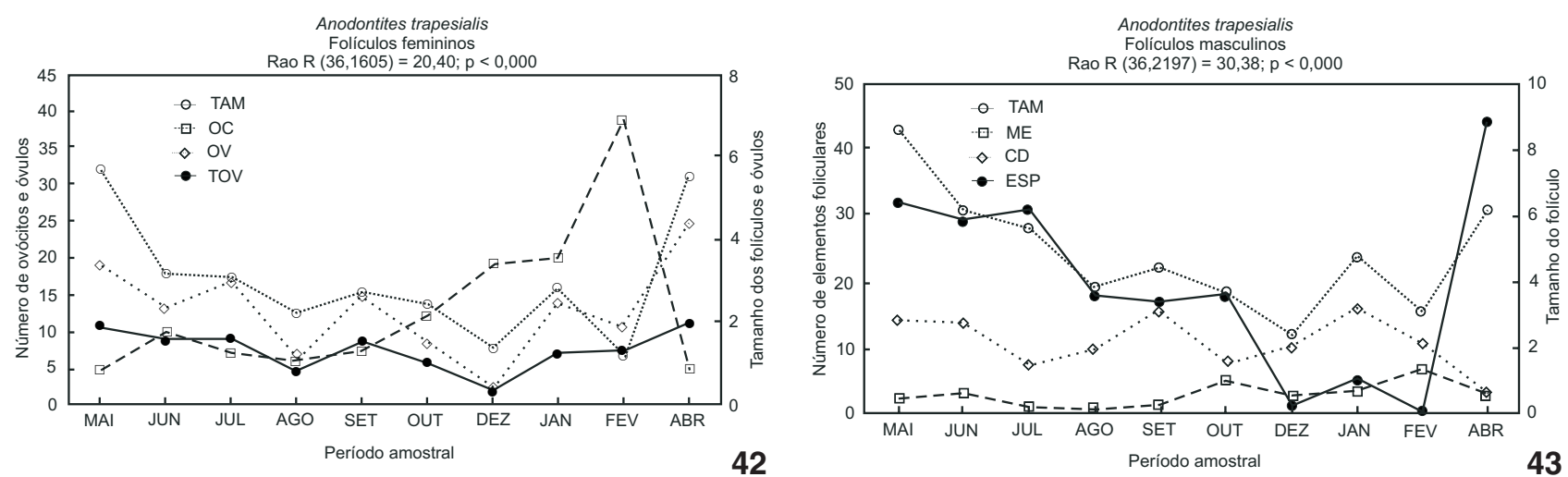

Figuras 42-43. 42. Distribuição mensal dos valores médios das variáveis gametogênicas nos folículos femininos (42) e masculinos (43) de Anodontites trapesialis, na Baía do Poço, Santo Antônio do Leverger, Mato Grosso. (TAM) Comprimento máximo do folículo, (OC) número de ovócitos, (OV) número de óvulos, (TOV) diâmetro do óvulo, (CD) número de células em desenvolvimento, (ME) número de mórulas espermáticas, (ESP) número de espermatozóides.

tamanho destas células (Fig. 22) e no aumento do tamanho dos folículos, pôde-se detectar que o pico de eliminação dos gametas femininos ocorreu em maio $(24,80 \pm 5,84$ óvulos maduros por folículo) culminando com o início da vazante (Fig. 42). O teste de Scheffé demonstrou que as diferenças são significativas $(\mathrm{p}<0,001)$ entre o mês de abril e os demais, exceto para maio e julho, onde ocorreram valores elevados de óvulos maduros por folículo. Entretanto foi possível observar em menor freqüência, espécimes com folículos maduros até outubro com um incremento suave no número de óvulos no mês de setembro (14,68 \pm 10,65 óvulos maduros por folículo). Durante o mês de dezembro, todos os indivíduos estavam esgotados, em estado de reversão folicular (Figs 15 e 17). As variações mensais frente à ausência de óvulos, foram significativas para os meses de dezembro e agosto quando comparadas com os demais meses do período amostral $(\mathrm{p}<0,001)$.

\section{Ciclo sexual masculino}

A espermatogênese ocorreu simultaneamente à produção dos gametas femininos (Tab. V). Foram observadas diferenças significativas relacionadas ao tamanho dos folículos, bem como do número dos elementos celulares gametogênicos ao longo do período amostrado (d.f. $1=36$, d.f. $2=2197 \mathrm{p}<0$,001) (Fig. 43). O tamanho dos folículos masculinos (Tab. VI) variou significativamente $(F=52,06$, d.f. $=9, p<0,0001)$ sendo que o mês de maio apresentou maiores valores quando comparado aos demais meses amostrados. O número de mórulas espermáticas, características da fase de proliferação celular (Fig. 27), apresentou os valores médios mais elevados entre os meses de outubro a fevereiro quando os folículos, ainda pequenos, são iminentes na massa visceral (Figs 30 e 31). As diferenças existentes frente ao número de mórulas espermáticas durante os meses amostrados foram demonstradas através da ANOVA $(\mathrm{F}=16,53$, d.f. $=9$, $\mathrm{p}<0,0001)$. A presença de células em desenvolvimento e diferenciadas (espermatócitos de primeira e segunda ordem e esper- mátides, Fig. 27) também apresentaram diferenças significativas ao longo dos meses $(F=20,48$, d.f. $=9$, $p<0,0001)$. Estes elementos celulares ocorrem paralelamente à fase de proliferação, apresentando dois picos bem definidos em setembro e em janeiro demonstrados pelo teste de Scheffè ( $\mathrm{p}<0,0001$ ) (Fig. 43). Quando estes elementos celulares são presentes, fica evidenciada a estrutura gametogênica denominada de série espermática radial. Nos meses subseqüentes, outubro e mais intensamente em abril, surgem os picos de produção dos espermatozóides ( $\mathrm{F}=$ $75,39$, d.f. $=9, \mathrm{p}<0,0001)$. Apesar de a atividade gametogênica ter sido observada durante a maior parte do ano (março a outubro), foi evidente uma drástica diminuição durante o período entre dezembro e fevereiro (teste de Scheffè, $\mathrm{p}<0,0001$ ).

Simultaneamente à fase de eliminação dos gametas masculinos, agregados de espermatozóides em forma de esferas "spermballs", foram freqüentemente observados em folículos que já haviam eliminado a maioria dos espermatozóides isolados. Nesta fase, próximos ao epitélio folicular, são reconhecidos pacotes celulares contendo elementos gametogênicos em diferentes estágios de desenvolvimento (Fig. 32), onde podem ser visualizadas mórulas espermáticas maiores, as quais provavelmente estejam associadas à origem das "spermballs" (Fig. 27).

\section{DISCUSSÃO}

Anodontites trapesialis pode ser caracterizada como hermafrodita funcional e simultâneo, uma vez que 86,30\% dos indivíduos analisados apresentaram folículos femininos e masculinos, 2,73\% possuíam folículos exclusivamente masculinos e 10,95\% não demonstraram atividade gonadal, nem mesmo sinais de formações foliculares. BONETTO (1951), considerou o hermafroditismo como caráter comum para o gênero Anodontites. Dentre os escassos estudos desenvolvidos no Brasil, Hebling (1976) abordou o gênero Anodontites e verificou a ocorrência de hermafroditismo em $A$. trapesialis, mas não comprovou o fato para $A$. 
Tabela V. Caracterização mensal da gametogênese nos folículos masculinos de Anodontites trapesialis na Baía do Poço, Santo Antônio do Leverger, Mato Grosso.

\begin{tabular}{|c|c|}
\hline Meses & Folículos masculinos \\
\hline Maio & $\begin{array}{l}\text { Folículos bem estruturados. Série espermática radial definida, mórulas espermáticas evidentes, ocorrendo } \\
\text { geralmente na fase de espermatogônias, formando várias camadas de células justapostas ao epitélio folicular. } \\
\text { Presença abundante de elementos maduros (espermatozóides) isolados no lúmem (Fig. 24). São observados } \\
\text { espermatozóides ao longo dos ductos que se encontram repletos de substância amarela intracelular de aparência } \\
\text { granulosa e translúcida (Fig. 25). }\end{array}$ \\
\hline Junho & $\begin{array}{l}\text { Distribuição esparsa de folículos masculinos na massa visceral. A estrutura folicular e a disposição das células são } \\
\text { semelhantes aos descritos para o mês anterior. Tendência de agrupamento dos espermatozóides no lúmem } \\
\text { central (Fig. 26). Ductos foliculares livres, com poucos elementos maduros; grânulos de substância amarela intra } \\
\text { e extracelular esparsos ao longo do epitélio. }\end{array}$ \\
\hline Julho a outubro & $\begin{array}{l}\text { Alguns indivíduos encontram-se em início de reversão folicular. Aqueles que ainda se encontram em atividade } \\
\text { sexual (Fig. 28), apresentam folículos em estado avançado de eliminação dos gametas. As séries espermáticas } \\
\text { encontram-se desorganizadas, as mórulas espermáticas são esparsas, entretanto é freqüente a presença de } \\
\text { "spermballs" (Fig. 27). Os ductos estão repletos de substância amarela intracelular, configurada em grânulos } \\
\text { translúcidos. É freqüente a presença de espermatozóides ao longo dos ductos (Figs } 25 \text { e 35). }\end{array}$ \\
\hline Dezembro & $\begin{array}{l}\text { A maioria dos indivíduos apresenta-se em estado de reversão folicular característico: Folículos escassos dispersos } \\
\text { na massa visceral (Fig. 29). De contorno irregular, quase sempre restando apenas fragmentos de tecido gonadal. } \\
\text { É possível visualizar células primordiais pequenas e uniformes e raros gametas residuais sobrepostos à massa } \\
\text { celular (Fig. 30). Há indivíduos ainda em eliminação de gametas onde é possível observar óvulos maduros no } \\
\text { interior de folículos masculinos. }\end{array}$ \\
\hline Janeiro e fevereiro & $\begin{array}{l}\text { Folículos em desenvolvimento, ocupando parcialmente a massa visceral. Fase de intensa proliferação celular (Fig. } \\
\text { 31). Espaço folicular ocupado completamente por células primordiais (espermatogônias) não diferenciadas, } \\
\text { basófilas. Presença de mórulas espermáticas (Fig. 32). Ocorrência de gametas femininos juntamente com } \\
\text { masculinos ao longo dos ductos. Alguns indivíduos ainda estão eliminando gametas. }\end{array}$ \\
\hline Abril & $\begin{array}{l}\text { Período de maturação máxima. Eliminação de espermatozóides. Folículos uniformes e abundantes. Série } \\
\text { espermática radial bem definida, lúmen folicular preenchido por espermatozóides isolados. Presença abundante } \\
\text { de gametas masculinos ao longo dos ductos, os quais apresentam as células epiteliais em processo de produção } \\
\text { e secreção de substância amarela (Figs 33-35). }\end{array}$ \\
\hline
\end{tabular}

Tabela VI. Variação mensal dos parâmetros considerados para os folículos masculinos em Anodontites trapesialis amostrados na Baía do Poço, Santo Antônio do Leverger, Mato Grosso. (Tam M) Comprimento máximo do folículo, (ME) número de mórulas espermáticas, (CD) número de células em desenvolvimento, (ESP) número de espermatozóides.

\begin{tabular}{lrrrr}
\hline \multicolumn{1}{c}{ Meses } & Tam M & ME & CD & ESP \\
\hline Mai/1998 & $8,60 \pm 2,88$ & $2,20 \pm 3,71$ & $14,08 \pm 7,53$ & $32,18 \pm 11,86$ \\
Junho & $6,20 \pm 2,77$ & $3,22 \pm 4,34$ & $13,82 \pm 7,98$ & $29,60 \pm 9,43$ \\
Julho & $5,64 \pm 2,77$ & $0,94 \pm 1,50$ & $7,74 \pm 4,28$ & $31,28 \pm 17,38$ \\
Agosto & $3,82 \pm 2,48$ & $0,82 \pm 1,25$ & $9,97 \pm 6,26$ & $18,23 \pm 20,29$ \\
Setembro & $4,47 \pm 1,75$ & $1,29 \pm 2,65$ & $15,94 \pm 10,68$ & $16,77 \pm 13,20$ \\
Outubro & $3,65 \pm 1,92$ & $5,25 \pm 5,13$ & $7,97 \pm 7,04$ & $18,28 \pm 14,62$ \\
Dezembro & $2,44 \pm 0,60$ & $2,85 \pm 4,09$ & $10,25 \pm 5,51$ & $1,60 \pm 2,82$ \\
Janeiro/1999 & $4,74 \pm 1,15$ & $3,50 \pm 1,15$ & $16,00 \pm 2,51$ & $5,30 \pm 5,62$ \\
Fevereiro & $3,10 \pm 1,39$ & $6,96 \pm 4,28$ & $10,64 \pm 4,23$ & $0,16 \pm 0,47$ \\
Abril & $6,17 \pm 0,85$ & $3,34 \pm 2,35$ & $3,34 \pm 5,19$ & $44,26 \pm 14,13$ \\
\hline
\end{tabular}

trapezeus (Spix, 1827). Estudando aspectos ecológicos de $A$. soleniformis (Orbgny, 1835) no riacho Chipiri, Bolívia, MALDoNADO et al. (1990) verificaram um padrão dióico para a espécie. Em revisão da sistemática e dos caracteres anatômicos, Simone (1994) também considerou A. trapesialis como hermafrodita.

Além da variabilidade que ocorre entre espécies, é comum os bivalves apresentarem variações intraespecíficas. Tais possibilidades sexuais em uma mesma espécie, e até mesmo em um único indivíduo, são detalhadas por CoE (1943), onde explica que a alternância entre machos, hermafroditas e fêmeas ao longo da vida é comum, principalmente em bivalves límnicos. Entre as diferentes categorias de hermafroditismo propostas pelo autor, 
A. trapesialis é caracteristicamente considerada como hermafrodita funcional normal, uma vez que a espécie predominantemente é monóica, com produção simultânea de gametas masculinos e femininos em um mesmo indivíduo, sendo estes gametas ocasionalmente eliminados por um ducto comum. Tal diversidade de padrões é prevista na categoria sexual apresentada por CoE (1943), o qual considera a possibilidade de que em algumas espécies, os elementos masculinos e femininos sejam produzidos em porções distintas da massa visceral, com gonoductos separados; em outras os folículos masculinos e femininos ocorrem juntos, entremeados uns aos outros, e ainda há aquelas espécies onde a produção de gametas masculinos e femininos podem acontecer dentro de um mesmo folículo. No caso de $A$. trapesialis, há folículos femininos e masculinos distintos, óvulos maduros foram observados no lúmem de folículos masculinos, junto às células da série espermática e espermatozóides. Tal situação também foi descrita para Actionaias ellipsiformes (Conrad, 1836) e Villosa iris (Lea, 1830). Schalie (1969) sugere que este comportamento pode ter se fixado em populações de espécies que vivem em locais onde o sucesso reprodutivo torna-se temporariamente difícil, e que a resposta aos "estímulos" ambientais que podem levar à essa estratégia de sobrevivência depende de uma estrutura genética e hormonal para que efetivamente ocorram.

Na Austrália, casos de hermafroditismo em espécies da família Unionidae (HASs 1969) foram reportados por Jones et al (1986) para Velesunio ambiguus (Philippi, 1847) e V. angasi (Sowerby, 1867) da sub-família Hyriinae. BYrne (1998) caracterizou Hyridella depressa (Lamarck, 1819) também pertencente aos Hyriinae, como microhermafrodita, onde uma pequena parcela de fêmeas apresentou resíduos de tecidos espermatogênicos. $\mathrm{Na}$ Índia tropical, Lamellidens corrianus (Lea 1834) sub-família Unioninae (HASS 1969), foi caracterizado como hermafrodita (NAGABHUSHANAN \& LOHGAONKER 1978). BAUER (2001) apresenta uma ampla discussão sobre as possíveis categorias sexuais presentes em nível de espécies, atribuindo à estas variabilidades desde processos microevolutivos até plasticidade fenotípica, ou ambos.

Entre os Unionoida vários registros têm associado um padrão contínuo à gametogênese, onde uma parcela da população sempre se encontra ativa e com elementos maduros (SCHALIE \& Schalie 1963, Heard 1975, Nagabhushanam \& LohgaOnKer 1978, Chung 1980, Kenmuir 1981, Jones et al. 1986, Byrne 1998). Quando a produção de óvulos e espermatozóides é permanente, comumente observam-se diferentes estágios de desenvolvimento ocorrendo simultaneamente. SASTRY (1979) definiu duas categorias de populações com base no tempo de desenvolvimento dos eventos nos ciclos reprodutivos: sincrônica, quando todos os indivíduos encontram-se em estágios de desenvolvimento gonadal semelhantes, mantendo um ciclo de desenvolvimento folicular simultâneo: assincrônica, quando a população apresenta constantemente indivíduos com gametas maduros, sendo que há períodos de proliferação e eliminação dos gametas nos quais uma parcela significativa da população pode ser assim caracterizada. Este fato, segundo o autor está associado principalmente a organismos de regiões tropicais.

Apesar de contínua, a g ametogênese dos A. trapesialis na Baía do Poço foi caracterizada por tendências frente aos estágios de maturação gonadal. O período de proliferação celular, tanto para os folículos femininos quanto para os masculinos, ocorreu em dois períodos compreendendo setembro-outubro e janeiro-fevereiro; a maturação máxima e eliminação dos gametas femininos ocorrem entre abril e maio sendo que a presença de óvulos maduros e folículos cheios também ocorreu em setembro e outubro; para os espermatozóides, o pico de produção e eliminação ocorreu entre abril e junho e após a eliminação de gametas, os indivíduos entraram em processo de reversão folicular, tanto em folículos oogênicos quanto nos espermatogênicos, durante os meses de dezembro a fevereiro. Parece que há uma tendência à homogeneidade quando analisados os períodos de maturação gonadal dos bivalves unionideos Sul-americanos. Mesmo que a maioria dos estudos sejam com Hyriidae, as épocas de maturação e eliminação de gametas foram coincidentes com aquelas observadas neste estudo. Em Diplodon chilensis chilensis (Gray, 1828) o pico reprodutivo foi registrado entre abril e agosto (Peredo \& Parada 1986), e em $D$. deledontus expansus (Küster, 1856) parece que a maior atividade gonadal ocorre em julho (Curial \& Lange 1975). Avelar \& Mendonça (1998) observaram dois períodos reprodutivos em Diplodon rotundus gratus (Lea, 1860) sendo que o primeiro aconteceu entre janeiro e julho, com o desenvolvimento masculino e feminino simultâneos e o segundo entre agosto e janeiro onde o número de hermafroditas funcionais decresceu. O pico de eliminação dos gametas ocorreu em abril, sendo que em agosto todos os indivíduos estavam em reversão folicular. Um padrão semelhante foi descrito para Paxydon syrmatophorus (Meuschen in Gronovius, 1781), o qual apresentou dois picos de maturação entre setembro-outubro e março-maio, para gametas masculinos e um período acentuado entre julho e agosto para os gametas femininos (Beasley et al. 2000).

O padrão gametogênico assumido pela população estudada, normalmente tem sido descrito como dependente de influências ambientais. A variação na temperatura (KeMnUIR 1981, Avelar \& Mendonça 1998) e o nível da água estimulam a liberação de gametas e larvas (BeAsLey et al. 2000). No Sudeste do Brasil, a gametogênese de Diplodon rotundus gratus (Lea, 1860) esteve associada à temperatura da água, sendo que em março, quando a temperatura começa a declinar, ocorre à liberação dos gametas sendo interrompida durante os meses de inverno quando os animais apresentam reversão folicular (Avelar \& Mendonça 1998). Peredo \& Parada (1986) também relacionaram o ciclo reprodutivo de $D$. chilensis chilensis (Gray, 1828) à temperatura, pois a produção e a maturação ocorreram no outono e no inverno e a desova na primavera e no verão.

Com valores de temperatura praticamente constantes, o fator que determina a produtividade dos ecossistemas no Pantanal, é o sistema de inundações periódicas caracterizado por quatro períodos sazonais definidos: enchente, cheia, vazante e

Revista Brasileira de Zoologia 24 (3): 825-840, setembro 2007 
seca. O pulso de inundação retroalimenta os fluxos de matéria e energia e controlam a dinâmica das populações aquáticas e terrestres que se encontram na ATTZ - Zona de Transição Terrestre e Aquática (Junk et al. 1989, Junk 2000). A disponibilidade continua de nutrientes, características da região neotropical, promove um padrão reprodutivo contínuo (BYRNE 1998).

A variação do nível de água como fator influente no ciclo reprodutivo também foi reconhecido para Paxydon symarthophorus (Muschen in Gronovius, 1871), que tem seu período de desova e incubação das larvas durante a estação seca (BEASLEY et al. 2000). Em Castalia ambigua ambigua (Lamarck, 1819) o período de maior ocorrência de fêmeas gravidas foi ao final da estação cheia e início da seca, entre os meses de maio a agosto (VALE et al. 2005). Ambas as espécies, $P$. syrmatophorus e C. a. ambigua foram estudadas da região Norte do Brasil, onde os valores de temperatura permanecem constantes durante todo o ano.

No hemisfério Norte, Anodonta grandis Say, 1829 apresenta um padrão de incubação das larvas do tipo "bradytictic" (incubação prolongada), descrita por Lewis (1985). Entretanto quando este autor observou um padrão "tachyticity" (incubação de curta duração), atribuiu o fato a uma estratégia adotada pela população, provavelmente influenciada pelo fluxo hidrológico.

O ciclo sexual de $A$. trapesialis, representado pela sucessão de eventos como a gametogêse, eliminação dos gametas, fecundação e incubação das larvas, parecem estar relacionados com o ciclo hidrológico imposto pelo fluxo de águas na região. A liberação dos gametas e presença de embriões nos marsúpios durante os meses de abril e maio, início de vazante, provavelmente estejam relacionados com a saída de peixes das "baías" e áreas de inundação adjacentes do canal principal do rio Cuiabá. Durante a enchente, muitas espécies de peixes realizam movimento lateral para a planície de inundação, retornando para o canal principal com a diminuição do nível da água (Lowe-McConnel 1999). As flutuações no nível da água influenciam diretamente nos movimentos migratórios de peixes, determinando assim padrões de migração trófica e reprodutiva. No Pantanal, o sincronismo dos eventos será mais uma vez demonstrada quando a hipótese de que existe interdependência entre: flutuação do nível da água, a migração lateral da ictiofauna e a liberação de larvas (gloquídeos e lasídios) de moluscos bivalves for comprovada.

Em bivalves Unionoida, 43 espécies pertencentes à 17 gêneros dentre as famílias Amblemidae, Hyriidae, Margaritiferidae e Unionidae apresentam mórulas espermáticas em alguma fase da espermiogênese (HEARd 1975). Para espécies de ocorrência brasileira, são encontrados registros destas estruturas em Diplodon rotundus gratus (Lea, 1860) (Avelar \& Mendonça 1998); Prisodon alatus (Sowerby, 1869) (Matos et al. 1998) e Paxydon syrmatophorus (BEASLEY et al. 2000).

Ainda não está definido se a ocorrência das mórulas espermáticas durante o processo de espermiogênese é um evento típico, ocorrendo em fases determinadas do ciclo sexual masculino (Matos et al. 1998). Consideradas como um evento de ocorrência sazonal, HEARD (1975) cita que as mórulas espermá- ticas em Villosa villosa (B. H. Wright, 1898) (Lampsilinae) e Anodonta peggyae Johnson, 1965, não sofrem citólise, mas originam espermatozóides indistinguíveis quanto à morfologia e tamanho, quando comparados com aqueles produzidos pela seqüência espermatogênica típica.

O desenvolvimento de vários clusters de espermátides formando mórulas em Prisodon alatus, foi considerado por Matos et al. (1998), como o resultado de uma espermiogênese natural na qual as espermátides sofrem metamorfose transformando-se em espermatozóides maduros. Tal processo, nesta espécie ocorre apenas nos estágios iniciais da espermiogênese, quando a mórula ainda precisa de suporte nutricional, concluindo que detalhes importantes da origem, desenvolvimento, ultraestrutura e função ainda não estão completamente conhecidos.

Em A. trapesialis o estágio de proliferação celular, é caracterizado pela ocorrência quase que exclusiva de mórulas espermáticas, as quais ocupam todo o volume folicular. Tal fase é sucedida pela presença de vários tipos celulares, característicos da série espermática radial. Em um posterior momento proliferativo, dando seqüência ao segundo pico reprodutivo, observase a presença de mórulas espermáticas de maior tamanho. Estão organizadas em pacotes que delimitam agrupamentos de células gemetogênicas diferenciadas, denominados genericamente por Matos et al. (1998) como células de Sertoli. Assim como "mórula espermática", a utilização do termo "célula de Sertoli", é mais uma adaptação da nomenclatura, sendo que tais terminologias apesar de amplamente utilizadas na literatura, não condizem especificamente com a origem e função celular das estruturas que designam. Para a espécie aqui considerada, a ocorrência de mórulas espermáticas tardias está possivelmente associada à origem das "spermballs", fato que caracteriza A. trapesialis como espermatozeugmatas (LyYn 1994).

A ocorrência de "spermballs" está associada à algumas das espécies sul americanas como Anodontites trapezeus (Hebling 1971) e Diplodon rotundus gratus (Hebling \& Penteado 1974). A função destas estruturas podem estar associada à eficiência durante o processo de fecundação, agindo como espermatóforos (EDGAR 1965). Como outra possibilidade, também poderia ser considerada a compatibilidade morfológica destes agregados celulares, frente ao processo de seleção de partículas pelos filamentos branquiais, uma vez que a fecundação dos Unionoida "marsupiais" se dá nos espaços intralamelares ou no canal suprabranquial. Considerando que, a maneira pela qual os espermatozóides se movem, está diretamente relacionada às condições ambientais (GILBERT 1994), tal abordagem abre um leque de questões paralelas à discussão de estratégias adaptativas para ocupação e dispersão dos grupos de bivalves através nas águas continentais.

\section{AGRADECIMENTOS}

Ao NEPA/UFMT, Projeto Ecologia do Pantanal/UFMT/Max Planck Institut für Limnologie, programa SHIFT-CNPq/BMBF. A Willibaldo Thomé, Laboratório de Malacologia, PUCRS, Alex Nuñer, Laboratório de Cultivo de Peixes de Água Doce e Aimê 
Raquel, Laboratório de Mexilhões, ambos da UFSC. Ao Museu de Ciências e Tecnologia, PUCRS, à Lívia Mondim e todos aqueles colaboraram para o desenvolvimento deste.

\section{REFERÊNCIAS BIBLIOGRÁFICAS}

Avelar, W.E.P. \& S.H.S.T. MendonçA. 1998. Aspects of gametogenisis of Diplodon rotundus gratus (Wagner, 1827) (Bivalvia: Hyriidae) in Brazil. American Malacological Bulletin 14 (2): 157-163.

BAUER, G. 2001. Life-History variation on different taxonomic levels of naiads. In: Evolution of the freshwater mussels Unionoida. Ecologicall Studies 145: 83-91.

Beasley, C.R.; E. Túry; W.G. Vale \& C.H. Tagliaro. 2000. Reproductive cycle, management and conservation of Paxydon syrmatophorus (Bivalvia: Hyriidae) from the Tocantins river, Brazil. Journal of Moluscan Studies 66: 393-402.

BonetTo, A.A. 1951. Acerca de las formas larvales de Mutelidae Ortmann. Jornadas Icticas 1 (1):1-18.

BonetTo, A.A. \& I.D. Ezcurra. 1962a. Nota preliminar sobre el desarollo del "Lasidium" de un Mutelido americano. Publicacion de la Direccion General de Recursos Naturales Ministerio Agricultura y Ganaderia 4 (1):1-3.

BonetTo, A.A. \& I.D. Ezcurra. 1962b. El desarrollo del Lasidium de Anodontites trapesialis forbesianus (LeA) (Moll. Lamell.) Physis 23 (65):195-203.

Byrne, M. 1998. Reproduction of river and lake populations of Hyridella depressa (Unionacea:Hyriidae) in New South Wales: implications for their conservation. Hydrobiologia 389: 2943.

CalliL, C.T. \& W.J. Junk. 1999. Concentração e incorporação de mercúrio por moluscos bivalves Anodotites trapesialis (Lamarck, 1819) e Castalia ambigua (Lamarck, 1819). do Pantanal de Poconé - MT, Brasil. Biociências 7 (2): 3-28.

Callil, C.T. \& W.J. Junk. 2000. Aquatic gastropods as mercury indicators in the Pantanal of Poconé region (Mato Grosso, Brasil). Journal of Water, Air and Soil Pollution 319: 319-330.

Chung, Y. 1980. Reproductive cycle and breeding season of the freshwater clam, Anodonta (Sinanodonta) woodiana (LEA). Bulletin of Korean Fisherie Society 13 (4): 135-144.

Coe, W.R. 1943. Sexual differentiation in mollusks. I. Pelecypods. The quarterly Review of Biology, 194: 154-164.

Curial, O. \& R.R. Lange. 1975. Variações histológicas sasonais das gônadas do Diplodon delodontus expansus (Küster) (Mollusca, Unionidade). Arquivos de Biologia e Tecnologia 18: 65-67.

EDGAR, A.L. 1965. Observation on the sperm of the pelecypod Anodontites ferussacianus (Lea). Transmission Microscopy Society 84 (2): 228-230.

GilberT, S.F. 1994. Biologia do desenvolvimento. Riberão Preto, Sociedade Brasileira de Genética, 578p.

Haggerty, T.; J. Gardner; G. Patterson \& J. Jones. 1995. A quantitative assessment of the reproductive biology of Cyclonaias tuberculata (Bivallvia: Unionidae). Canadian Journal of Zoology 73: 83-88.
HEARD, W.H. 1975. Sexuality and other aspects of reproduction in Anodonta (Pelecypoda: Unionidae). Malacologia 15 (1):81-103.

HaAs, F. 1969. Superfamilia Unionacea, p. 1-663. In: R. Mertens; W. Hennig \& H. Wermuth. Das Tierreich. Eine Zusammenstellung und Kennzeichnung der rezenten Tierformen. Berlim, Walter de Gruyter, vol. 88, X+663.

Hebling, N.J. 1976. The functional morphology of Anodontites trapezeus (Spix) and Anodontites trapesialis (Lamarck). Bivalvia:Mycetopodidae). Boletim de Zoologia: 265-298.

Hebling, J.N. \& A.M.G. Penteado. 1974. Anatomia funcional de Diplodon rotundus gratus (Wagner, 1827) (Mollusca, Bivalvia). Revista Brasileira de Biologia 4 (1): 67-80.

Jones, H.A.; R.D. Simpson \& C.L. HuMPhREy. 1986. The reproductive cycles and glochidia of Fresh-water mussels (Bivalvia: Hyriidae) of the Macleay river, Northern New South Wales, Australia. Malacologia 27 (1): 185-202.

Junk, W.J. 2000. The Amazon and the Pantanal: A critical comparison and lessons for the future, p. 211-224. In: F.A. SWARTS (Ed.). The Pantanal: understanding and preserving the worlds largest wetland. Minnesota, Paragon House, 294p.

Junk, W.J.; P.B. Bayley \& R.E. Sparks. 1989. The flood pulse concept in river-floodplain systems. Canadian Special Publication of the Fisheries Aquatic Science 106: 110-127.

Kenmuir, D.H.S. 1981. Repetitive spawning behavior in two species of freswater musels (Lamellibranchiata: Unionacea) in Laje Kariba. Canadian Special Action of the Fisheries Aquatic Science 60 (8): 49-56.

Lewis, J.B. 1985. Breeding cycle of the freswater mussel Anodonta grandis Say. Canadian Journal of Zoology 63: 2477-2478.

Lowe-McconnelL, R.H. 1999. Estudos ecológicos de comunidades de peixes tropicais. São Paulo, EDUSP, 543p.

LyYN, J.W. 1994. The ultraestructure of the sperm and motile spermatozeugmata released from the freswater mussel Anodonta grandis (Mollusca, Bivalvia, Uninidae). Canadinan Journal of Zoology 72: 1452-1461.

Maldonado, M.; F. Acosta; L.J. Isurza \& C. Barra. 1990. Aspectos biologicos de Anodontites soleniformis (Mollusca-Bivalvia) en el Arroyo Chipiriri (Cochabamba-Bolivia). Acta Limnologica Brasiliensia 3: 847-863.

Matos, E.; L. Coral \& C. Azevedo. 1998. Fine structure of spermiogenesis with special reference to the spermatid morulae of the freshwater mussel Prisodon alatus (Bivalvia, Unionoidea). Journal of Morphology 238: 63-70.

Nagabhushanam, R. \& A.L. Loghaonker. 1978. Seasonal raproductive cycle in the mussel, Lamellidens corrianus. Hydrobiologia 61(1): 9-14.

Peredo, S. \& E. PARAdA. 1986. Reproductive cycle in the freshwater mussel Diplodon chilensis chilensis (Mollusca: Bivalvia). The Veliger 28 (4): 418-425.

SAStry, A.N. 1979. Pelecypoda (excluding Ostreidae), p. 113-292. In: A.C. Giese \& J.S. Pearse (Eds). Reproduction of Marine 
Invertebrates.V Molluscs: Pelecypods and Lesser Classes. New York, Academic Press, 369p.

Schalie, H. van Der. 1969. Two unsual Unionoid hermaphrodits. Science 163: 1333-1334.

SCHALIE, H. VAN DER \& A. van DER SChalie. 1963. The distribuition, ecology, and life history of the mussel, Actionaias ellipsiformis (Conrad), in Michigan. Occasional papers of the Museum of University of Michigan 663: 1-17.

Semenas, L. \& N. Brugni. 2002. Características populacionais e ciclo de vida de Diplodon chilensis (d'Orbgny, 1835) (Hyriidae,
Bivalvia) en el lago Gutiérrey (Patagonia, Argentina). Ecologia Austral 12: 29-40.

SimOne, L.R.L. 1994. Anatomical characters and systematics of Anodontites trapesialis (Lamarck, 1819) from South America (Mollusca, Bivalvia, Unionoida, Muteoloidea). Studies on Neotropical Fauna and Environment 29 (3): 169-185.

Vale, R.S.; C.R. Basley; C.H. Tagliaro \& M.C. Mansur. 2005. The glochidium and marsupium of Castalia ambigua Lamarck, 1819, from northen Brazil. American Malacological Bulletin 20: $43-48$.

Recebido em 15.II.2007; aceito em 31.VIII.2007. 